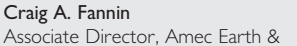
Associate Director, Amec Earth \& Environmental, Colchester, UK

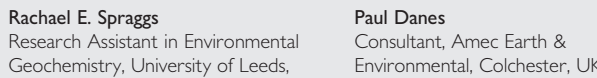

Geochemistry, University of Leeds, UK
Robert J. G. Mortimer Senior Lecturer in Environmental Geochemistry, University of Leeds, UK

\title{
Wetland system for primary treatment of landfill leachate
}

\author{
C. A. Fannin PhD, R. E. Spraggs PhD, P. Danes BSc and R. J. G. Mortimer PhD
}

\begin{abstract}
A proprietary constructed wetland system has been developed as a long-term sustainable alternative for the treatment of high-nitrogen effluents such as landfill leachates. The system design is an enhancement of the microbiological processes that occur naturally in saltmarsh systems and extends the process capability of traditional vertical-flow constructed wetlands.

Performance monitoring has demonstrated treatment rates of $69-95 \%$ per cell from a methanogenic landfill leachate influent containing $1400 \mathrm{mg} / \mathrm{l}$ ammoniacalnitrogen at both pilot and laboratory scale. Two systems are currently being commissioned in the UK and applications for a further two systems are being considered by the UK Environment Agency.
\end{abstract}

\section{INTRODUCTION}

As understanding of constructed wetlands (or reed beds) in wastewater management has increased over recent years, they are starting to be considered as a long-term sustainable treatment solution for effluents with high biological oxygen demand (BOD) and ammoniacal-nitrogen $\left(\mathrm{NH}_{4}-\mathrm{N}\right)$. Previous wastewater treatment research has focused on 'highperformance' systems such as reverse osmosis (RO) and membrane biological reactors (MBRs). The advantages of these processes over sequencing biological reactors (SBRs) at wastewater treatment works are their high capacity and performance with minimal operational footprints; they are therefore particularly cost-effective when treating large amounts of wastewater at sites where space is limited. The disadvantages are high cost and the need for power and management. In circumstances where power and management are unavailable, passive treatment systems such as constructed wetlands are more appropriate. Constructed wetlands can provide a sustainable and cost-effective alternative, albeit at a less efficient rate and with a larger footprint than other technologies.

Constructed wetlands have been widely used to treat wastewater, for example for the treatment of low-strength landfill leachates, ${ }^{1}$ nitrogen from agricultural wastes, ${ }^{2}$ reduction in BOD for wastewater treatment in rural or other locations not connected to mains sewers, ${ }^{3}$ as denitrification units for tertiary treatment in conjunction with nitrifying sewage treatment works and to manage storm flows ${ }^{4}$ or as sulphate-reducing systems to remove iron, arsenic and priority metals from mine effluents. ${ }^{5}$ Most contaminants can be treated to some degree in a constructed wetland. Specific treatment processes are based on promoting and managing the classical biogeochemical zones ${ }^{6}$ formed as a consequence of microbial activity in saturated soil environments to achieve the necessary treatment objectives.

The most sustainable wetland systems are based on soil microbial respiration. During microbial respiration, an electron is transferred from an oxidant (e.g. organic carbon) to a terminal electron acceptor (TEA) (e.g. oxygen) that provides energy for growth. During oxidation of organic matter, the biogeochemical zones represent a progression through these microbially mediated redox couples with the most energetically favourable proceeding first until depletion of the TEA. ${ }^{7-9}$ The biogeochemical zones are defined by the distinct distribution of pore-water species (Table 1). However, recent research has found this scheme to be an over-simplification; the classical view breaks down at the microcosm scale to both vertical and lateral progression with distance from each TEA source if appropriate bacteria are present. In addition, recycling processes such as denitrification under aerobic conditions ${ }^{10}$ or coupled manganese reduction and anoxic nitrification ${ }^{11}$ complicate the picture further.

Four primary reaction pathways have been identified for the transformation of ammonium into nitrogen. ${ }^{12-15}$

Traditionally, the coupled nitrification-denitrification pathway (Equations 1-3) was considered to be the only permanent method of removing nitrogen from wastewater. Nitrification can be illustrated by

$$
\mathrm{NH}_{4}^{+}+1 \cdot 5 \mathrm{O}_{2}+2 \mathrm{HCO}_{3}^{-} \rightarrow \mathrm{NO}_{2}^{-}+2 \mathrm{CO}_{2}+3 \mathrm{H}_{2} \mathrm{O}
$$

or

$$
2 \quad \mathrm{NO}_{2}^{-}+0 \cdot 5 \mathrm{NO}_{2}^{-} \rightarrow \mathrm{NO}_{3}^{-}
$$

while denitrification may be represented by

$$
\mathrm{CH}_{2} \mathrm{O}+0 \cdot 8 \mathrm{NO}_{3}^{-}+0 \cdot 8 \mathrm{H}^{+} \rightarrow \mathrm{CO}_{2}+0 \cdot 4 \mathrm{~N}_{2}+1 \cdot 4 \mathrm{H}_{2} \mathrm{O}
$$

More recently, the discovery of anaerobic ammonium oxidation, or anammox, (Equation 4) in a denitrifying glass fluidised bed 


\begin{tabular}{|c|c|c|}
\hline Process & TEA & Product \\
\hline Aerobic respiration & $\mathrm{O}_{2}$ & $\begin{array}{l}\text { Conversion of organic carbon to } \mathrm{CO}_{2} \\
\text { Conversion of organic nitrogen to } \mathrm{NO}_{3}^{-} \\
\text {Conversion of ammonium to } \mathrm{NO}_{3}^{-}\end{array}$ \\
\hline Denitrification & $\mathrm{NO}_{3}^{-}$ & Conversion to $\mathrm{N}_{2}$ \\
\hline Manganese reduction & Mn oxide & Conversion to $\mathrm{Mn}^{2+}$ \\
\hline Iron reduction & Fe oxyhydroxide & Conversion to $\mathrm{Fe}^{2+}$ \\
\hline Sulphate reduction & $\mathrm{SO}_{4}^{2-}$ & Conversion to $\mathrm{H}_{2} \mathrm{~S}$ \\
\hline Methanogenesis & $\mathrm{CO}_{2}$ & Conversion to $\mathrm{CH}_{4}$ \\
\hline
\end{tabular}

a rate significantly in excess of terrestrial plants.

Salt marsh plants have adapted to these conditions and provide a buffer between the plant rhizomes and high dissolved hydrogen sulphide concentrations that are toxic to all but anaerobic biota. This ability to thrive in a highly reduced environment and funding under the landfill tax

reactor ${ }^{16}$ has challenged this view by removing ammonium in a one-step reaction with nitrite. ${ }^{17}$

$$
4 \quad \mathrm{NH}_{4}^{+}+\mathrm{NO}_{2}^{-} \rightarrow \mathrm{N}_{2}+2 \mathrm{H}_{2} \mathrm{O}
$$

Anammox has attracted much attention since its discovery in 1995 and has been observed in both sediments and the water column in many locations. ${ }^{18,19}$ Some studies estimate that up to $50 \%$ of nitrogen produced in the marine environment could be due to anammox, indicating its significance in global nitrogen cycling. $^{20,21}$

Amec's Halotech system ${ }^{22}$ was developed to couple aerobic and anaerobic processes for the complete conversion of ammonium to nitrogen gas by combining process elements from proven systems for the treatment of landfill leachate. However, the parallel treatment of dissolved organic matter and priority substances is also required.

Mature landfill leachates are saline, strongly reducing effluents commonly saturated in dissolved methane, carbon dioxide and sulphide - that is, similar to the highly anaerobic sulphatereducing and methane-producing conditions found in salt marsh systems. ${ }^{18,23}$ These highly reducing conditions are often toxic to vegetation. However, aerobic processes (including nitrification) are supported in the immediate vicinity of salt marsh plant rhizomes ${ }^{24,25}$ by the active transfer of oxygen to the sediment at credit scheme has led to the investigation and development of a salt marsh based system for the treatment of high ammonium bearing effluents such as landfill leachates.

\section{METHODOLOGY}

\section{I. System overview}

The Halotech system is designed to operate as a saturated vertical flow wetland (Figure 1) for the treatment of influent solutions containing $1500 \mathrm{mg} / \mathrm{l} \mathrm{ammoniacal-nitrogen.} \mathrm{In}$ contrast to many vertical flow systems, which operate on a pulsed dosage arrangement into an unsaturated column that drains between dose pulses and are dependent on atmospheric oxygen ingress, this system is operated with an artificially controlled saturation level. Salt marsh plants supplement surface oxygen ingress and careful control of saturation levels allows complementary aerobic and anoxic microcosms to develop. ${ }^{26}$

Each wetland comprises an engineered containment cell, a basal drainage layer and treatment substrate (Figure 1). The treatment substrate is a planted artificial soil using a mixture of compost and sand selected to provide the required hydraulic properties as well as topsoil to provide a natural bacterial seed population for treatment. Although the biomass in the trials discussed here utilised the natural soil bacterial population as the source material, future bacterial populations are expected to be obtained from a combination of natural sources and established Halotech systems. Compost is an important component of the

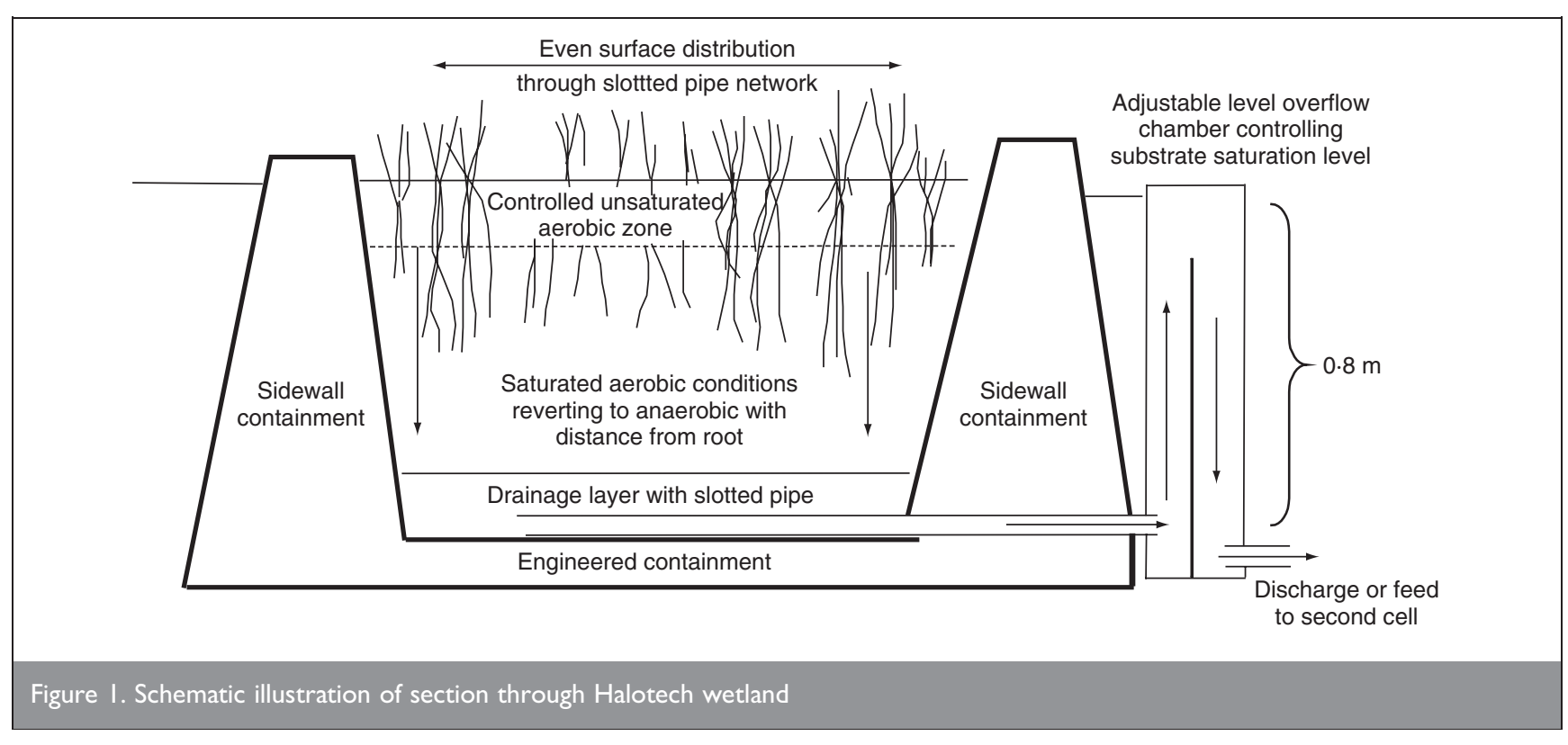




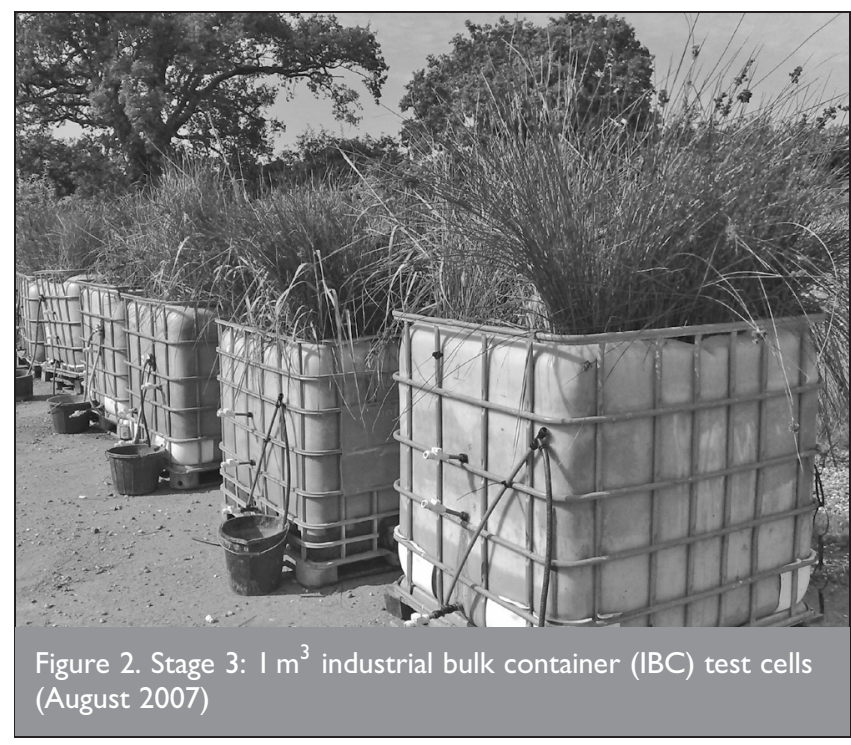

wetland matrix as it overcomes the hydraulic difficulties found in early wetland systems using soil substrates, ${ }^{27}$ yet allows for a larger surface area to support the treatment biomass than that provided by gravel beds. For the $1 \mathrm{~m}^{3}$ test cells (Figure 2), samples of influent solution were taken at $0 \mathrm{~m}$ depth and intermediate sampling points installed at $0.25 \mathrm{~m}$ and $0.5 \mathrm{~m}$. An effluent sample was obtained from a sampling point in the basal drainage layer at $0.75 \mathrm{~m}$.

\subsection{Investigations}

Development has followed an iterative process, in combination with published studies; ${ }^{10-31}$ trials are used to progressively understand and optimise the system for preferred outcomes. Initial trials demonstrated that the plants could thrive when dosed with a leachate solution with an artificially managed saturation level near the soil surface and that ammonia/ammonium toxicity can be overcome. In addition, nitrification processes were established and demonstrated that ammoniacal-nitrogen could be reduced within a soil-plant system. This paper reports on the latest stage of the development trials (stage 3) carried out in parallel with full-scale construction to optimise the commissioning process; an overview of the earlier stages (stages 1 and 2) is also provided.

2.2.1. Stage 1. This stage aimed to demonstrate that plant species can tolerate leachate solutions and identify preferred mechanisms - that is, that nitrification can occur from dosing $1500 \mathrm{mg} / \mathrm{l}$ ammoniacal-nitrogen. The trial comprised

(a) a series of 7-litre containers

(b) a series of 24 pairs of 30-litre containers operated in series.

\subsubsection{Stage 2. The second development stage was to} demonstrate ammonium treatment to below sewer discharge thresholds and that processes are sustained over the seasonal cycle. Mechanisms and process controls were identified for other required treatment mechanisms. The stage involved

(a) eight mobile $1 \mathrm{~m}^{3}$ industrial bulk container (IBC) systems based on operational sites

(b) two $200 \mathrm{~m}^{2}$ pilot-scale systems for the treatment of municipal waste effluent (as a nitrification system) and cement kiln dust

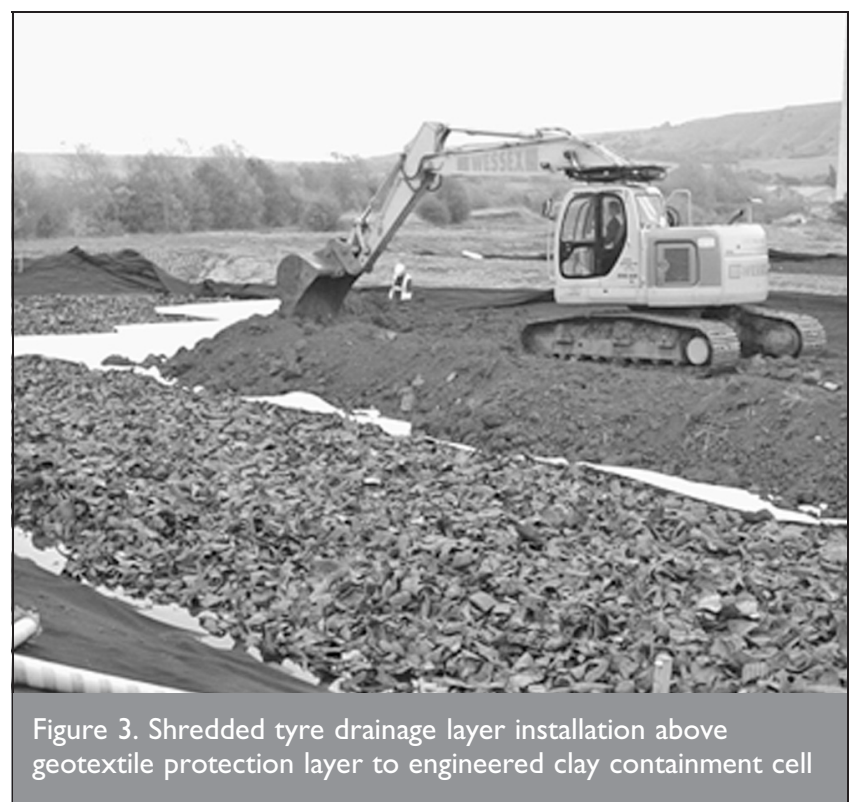

effluent (as a sulphate-reducing system) on UK sites in Wiltshire and Kent, respectively

(c) columns (2 m long, $0.4 \mathrm{~m}$ diameter) at Amec's laboratories

(d) trials at Leeds University to evaluate complementary anaerobic processes.

\subsubsection{Stage 3. Stage 3, to demonstrate that surface water} discharge can be achieved and that acclimatisation/biomass development is optimised, involved

(a) four mobile $1 \mathrm{~m}^{3}$ IBC systems based at Amec premises (Figure 2)

(b) the construction of two full-scale systems during 2007, ready for commissioning in 2008 .

Conclusions from the stage 2 trials ${ }^{28}$ demonstrated that influent ammoniacal-nitrogen could be reduced by $88 \%$, and this led to the construction (Figures 3 and 4) of two full-scale systems that are currently being commissioned. The first of these systems comprises a pair of $3500 \mathrm{~m}^{2}$ cells in series for the treatment of $85 \mathrm{~m}^{3} /$ day of landfill leachate.

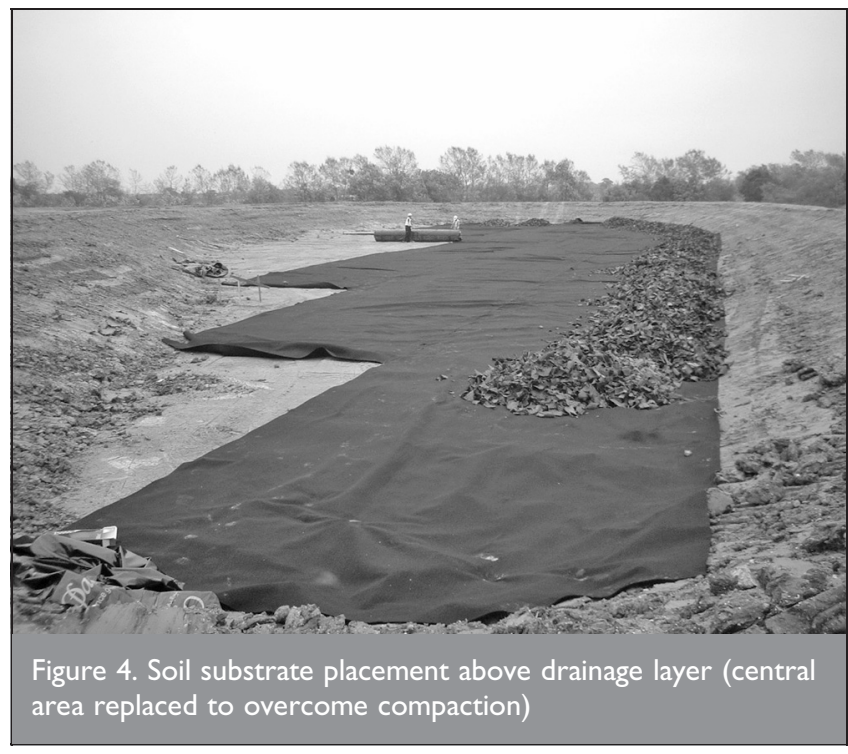


MSW leachate composition: $\mathrm{mg} / \mathrm{l}$

\begin{tabular}{lrrr} 
& Min. & Mean & Max. \\
\cline { 2 - 4 } & 335 & 790 & 1500 \\
Ammoniacal-nitrogen & 873 & 2050 & 5575 \\
Chemical oxygen demand & 6 & 47 & 121 \\
Biological oxygen demand & 620 & 1731 & 4000 \\
Chloride & & &
\end{tabular}

Table 2. Test MSW leachate composition, site range 2007 monitoring programme

Stage 3 evaluations were carried out during 2007-2008 using four $1 \mathrm{~m}^{3}$ IBC systems as described in Section 2.1. The IBC systems were constructed in August 2006. They were planted with Spartina and Juncus species obtained from a commercial grower and the systems were saturated with groundwater before beginning leachate dosing after a four-week establishment period.

A methanogenic leachate (Table 2) from a municipal solid waste (MSW) site was diluted to a preset ammonium concentration (initially $150-200 \mathrm{mg} / \mathrm{l}$ ); this was then dosed to each IBC as a daily pulse at a rate of 10 litres $/ \mathrm{m}^{2}$. Leachate was collected monthly from a single MSW location and was stored in a cold store at $<5^{\circ} \mathrm{C}$ throughout the trial. Each system was commissioned independently based on controlled, stepped ammoniacal-nitrogen concentration increases during the trials by diluting the leachate with groundwater to concentration ranges of

(a) 150-200 mg/l (starting influent, August 2006 to March 2007)

(b) $400-600 \mathrm{mg} / \mathrm{l}$

(c) $700-850 \mathrm{mg} / \mathrm{l}$

(d) $1100-1300 \mathrm{mg} / \mathrm{l}$

(e) $1400-1750 \mathrm{mg} / \mathrm{l}$.

The influent ammoniacal-nitrogen concentration was increased at a rate consistent with the biomass growth rate and observed ammonium and total nitrogen treatment rate in the upper and effluent sampling ports. As a consequence of differing observed treatment rates, influent ammoniacal-nitrogen concentrations across the four IBCs ranged from 660 to $1400 \mathrm{mg} / \mathrm{l}$ by September 2007 (as illustrated in Table 3). Continued biomass development was observed during September and October 2007. Influent concentrations were not increased during October 2007 to March 2008 (the period when winter temperatures are most likely to inhibit biomass growth and senescence to limit oxygen transfer to the soil) in order to demonstrate winter performance capability.

\section{TREATMENT CAPABILITY}

The stage 3 trials demonstrated a high level of performance during summer, autumn, winter and the following spring. During the summer period, evapotranspiration was equivalent to influent dosing rates of $100 \mathrm{~m}^{3} /$ ha plus incident rainfall. During this period, the saturation level could not be maintained in the upper $0.25 \mathrm{~m}$ of the soil substrate and there was a significant soil moisture deficit between June and August. Significant evapotranspiration occurred and overall discharge volumes were less than 5\% of influent dosed volumes even following heavy rainfall events. Complete nitrogen removal was observed during this period. Although the nitrogen reduction mechanisms could not be observed directly, they are likely to include surface sorption processes or increased biological activity from the soil moisture and temperature conditions during this period.

Ammoniacal-nitrogen removal rates of 69-99\% were recorded for each system outside the May-October growing season and continuous throughout the autumn to summer period (Table 3, Figure 5). Saturation levels were managed by an adjustable overflow control linked to the basal effluent port during this period. In all cells there was an overall parallel reduction of both ammoniacal-nitrogen and nitrogen in the upper $0.25 \mathrm{~m}$ of each cell (Figure 6) and over 70\% ammonium reduction occurred within this zone.

The overall treatment varied slightly (Table 4) even though the operation of individual systems only varied by influent loading concentrations. An excess of nitrate was observed for test cells IBC2 and IBC3. For IBC3, complete ammoniacalnitrogen treatment was observed by the $0.25 \mathrm{~m}$ sampling port between October and December (Figure 6), followed by denitrification between the 0.5 and $0.75 \mathrm{~m}$ sampling ports. Concurrent ammoniacal-nitrogen and total nitrogen reduction was observed for IBC1 and IBC4. Within these systems, there was a consistent reduction in ammoniacal-nitrogen in the upper $0 \cdot 25 \mathrm{~m}$ to less than $100 \mathrm{mg} / \mathrm{l}$ with limited nitratenitrogen (i.e. less than $100 \mathrm{mg} / \mathrm{l}$ and less than $50 \mathrm{mg} / \mathrm{l}$ for IBC1 and IBC4 respectively) at this depth. Ammoniacalnitrogen reduction continued in IBC4; however, no further treatment was observed for IBC 1 at $0.5 \mathrm{~m}$ and $0.75 \mathrm{~m}$ and nitrate was not present at these depths.

Ammoniacal-nitrogen reduction and total nitrogen reduction were sustained between January and April. However, there

\begin{tabular}{|c|c|c|c|c|c|}
\hline & $\begin{array}{c}\text { Influent } \\
\text { ammoniacal-N: mg/l }\end{array}$ & $\begin{array}{l}\text { Ammoniacal-N } \\
\text { reduction rate: \% }\end{array}$ & $\begin{array}{c}\text { Effluent } \\
\text { ammoniacal-N: } \mathrm{mg} / \mathrm{l}\end{array}$ & $\begin{array}{c}\text { Effluent } \\
\text { nitrate-N: } \mathrm{mg} / \mathrm{l}\end{array}$ & $\begin{array}{c}\text { Effluent } \\
\text { nitrogen: } \mathrm{mg} / \mathrm{l}\end{array}$ \\
\hline $\mid \mathrm{BCl}$ & 660 & 85 & 100 & $<5$ & $24-100$ \\
\hline $\mathrm{IBC2}$ & 1100 & 69-77 & $250-350$ & $<5-120$ & $250-470$ \\
\hline \multirow[t]{2}{*}{ IBC3 } & 1400 & $>99$ & $<5$ (autumn) & 300 (autumn) & 300 (autumn) \\
\hline & & $>95$ & 62 (winter) & $<5$ (winter) & 62 (winter) \\
\hline IBC4 & 700 & $>97$ & $15-22$ & $<5$ & $15-22$ \\
\hline
\end{tabular}




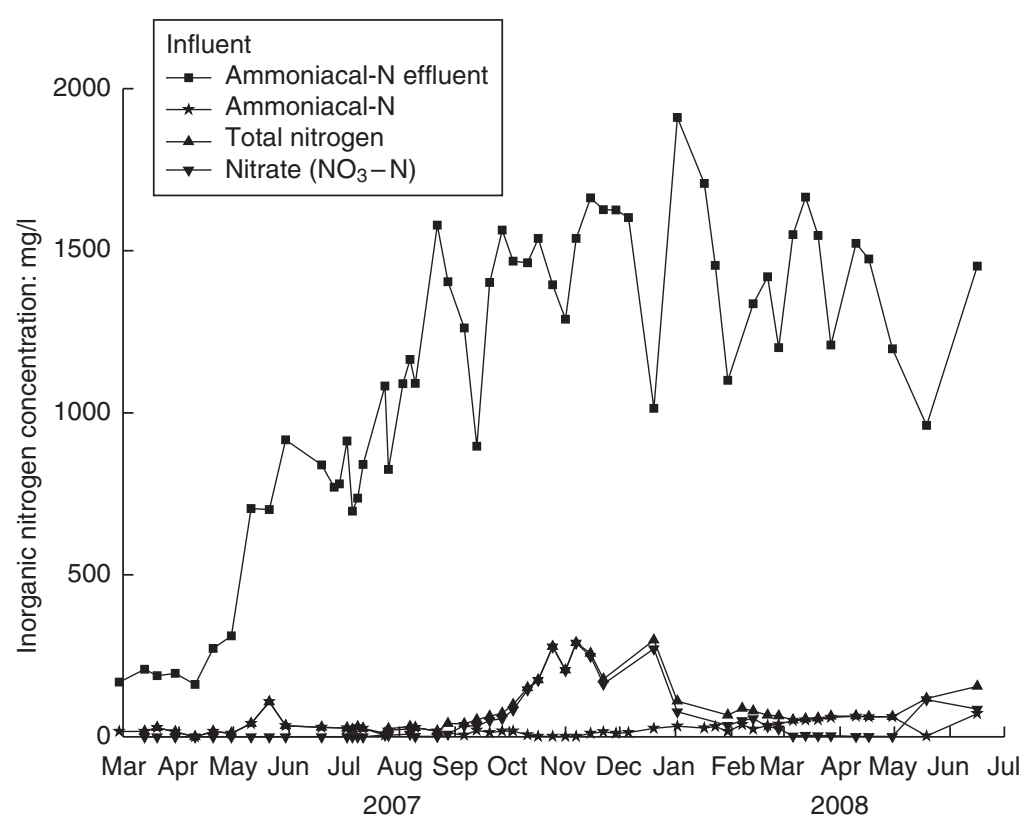

Figure 5. Seasonal ammonium and nitrogen treatment profiles (IBC3) March 2007-June 2008

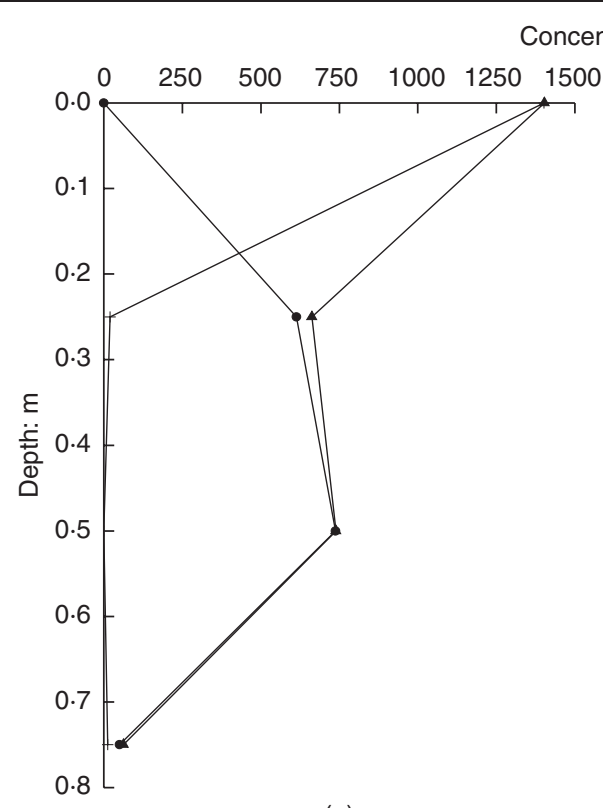

(a)

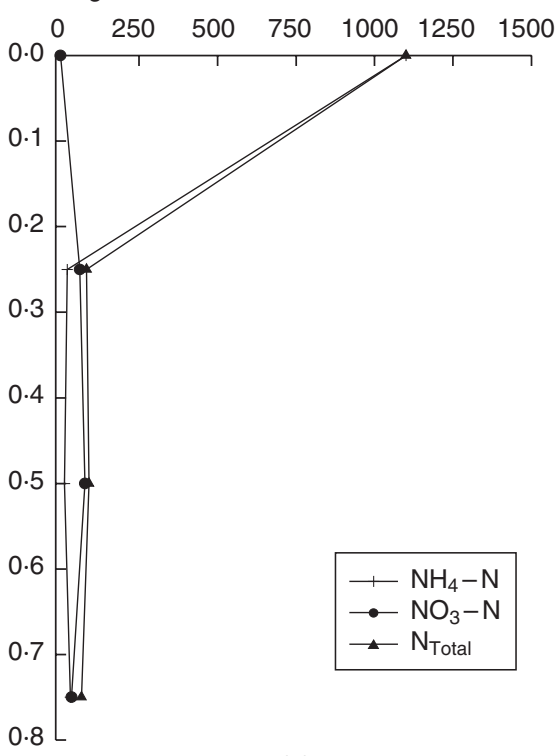

(b)

Figure 6. Depth profiles (IBC3) indicating the extent of nitrification and denitrification during autumn and winter: (a) IBC3 October; (b) IBC3 January

\begin{tabular}{|ll|}
\hline Test system & Process overview \\
\hline IBC3 & $\begin{array}{l}\text { Complete nitrification in upper levels resulting in insufficient ammonium to support anammox in mid-layer, until depth/ } \\
\text { oxygen depletion levels were sufficient to support denitrification. During autumn, nitrification was in excess of } \\
\text { denitrification, resulting in total ammonium removal, but relatively high }(300 \mathrm{mg} / \mathrm{l}) \text { total nitrogen effluent }\end{array}$ \\
IBC2 & $\begin{array}{l}\text { Continued denitrification/anammox processes throughout the depth profile, although nitrification level in excess of } \\
\text { anammox and potential ammonification concurrent with anammox from } 0.5-0.75 \mathrm{~m} \text { limiting overall performance }\end{array}$ \\
IBC4 & $\begin{array}{l}\text { Consistent anammox or other equivalent process throughout profile; high overall level of performance } \\
\text { Concurrent nitrification with denitrification and/or anammox in upper level, followed by denitrification of residual } \\
\text { (minor) nitrate at } 0.5-0.75 \mathrm{~m}\end{array}$ \\
\hline Table 4. Inferred process mechanism
\end{tabular}




\begin{tabular}{|c|c|c|c|c|c|c|c|c|c|}
\hline & \multicolumn{2}{|c|}{ Volume: I/week } & \multicolumn{3}{|c|}{ Concentration: mg/l } & \multicolumn{4}{|c|}{ Load: g/week } \\
\hline & \multirow[t]{2}{*}{ Influent } & \multirow[t]{2}{*}{ Effluent } & \multirow{2}{*}{$\frac{\text { Influent }}{\mathrm{NH}_{4}^{-} \mathrm{N}}$} & \multicolumn{2}{|c|}{ Effluent } & \multirow{2}{*}{$\frac{\text { Influent }}{\mathrm{NH}_{4}^{-} \mathrm{N}}$} & \multicolumn{3}{|c|}{ Effluent } \\
\hline & & & & $\mathrm{NH}_{4}^{-} \mathrm{N}$ & $\mathrm{NO}_{3}^{-} \mathrm{N}$ & & $\mathrm{NH}_{4}^{-} \mathrm{N}$ & $\mathrm{NO}_{3}^{-} \mathrm{N}$ & Total \\
\hline \multicolumn{10}{|l|}{ IBC2 } \\
\hline September & 70 & $<3$ & 1100 & 125 & 0 & 77 & $<0.4$ & 0 & $<0.4$ \\
\hline November & 70 & 86 & 1100 & 200 & 275 & 77 & $17 \cdot 2$ & $23 \cdot 7$ & 40.9 \\
\hline $\begin{array}{l}\text { February } \\
\text { IBC3 }\end{array}$ & 70 & 86 & 1100 & 350 & 120 & 77 & $30 \cdot 1$ & $10 \cdot 3$ & $40 \cdot 4$ \\
\hline September & 70 & $<3$ & 1400 & $2 \cdot 5$ & $<5$ & 98 & $<0.01$ & 0 & $<0.01$ \\
\hline November & 70 & 86 & 1400 & $2 \cdot 5$ & 300 & 98 & 0.2 & $25 \cdot 8$ & $26 \cdot 0$ \\
\hline $\begin{array}{l}\text { February } \\
\text { IBC4 }\end{array}$ & 70 & 86 & 1400 & 62 & $<5$ & 98 & $5 \cdot 3$ & 0 & $5 \cdot 3$ \\
\hline September & 70 & $<3$ & 660 & 15 & $<5$ & 46 & $<0.05$ & 0 & $<0.05$ \\
\hline November & 70 & 86 & 660 & 15 & $<5$ & 46 & $1 \cdot 3$ & 0 & $1 \cdot 3$ \\
\hline February & 70 & 86 & 660 & 22 & $<5$ & 46 & 1.9 & 0 & 1.9 \\
\hline
\end{tabular}

was no direct evidence of nitrification and concurrent ammonium and nitrogen was observed (Figures 5 and 6).

\section{DISCUSSION}

The results from this study and the earlier stage 2 trials ${ }^{28}$ demonstrate that ammoniacal-nitrogen can be treated successfully within a constructed wetland system, with treatment rates in excess of 65\% consistent across sequential cells. Inorganic nitrogen mass balance calculations from this study (Equations 5 and 6, Table 5) demonstrate that the effluent ammonium and nitrate load are negligible during the summer period when evaporation rates are maximum and are low during the winter period when nitrification appears to be limited. However, effluent inorganic nitrogen levels can increase during the autumn, in association with increased nitrate in the effluent. The influent ammoniacal-nitrogen load ( $\mathrm{g} /$ week per $\mathrm{m}^{2}$ ) is equal to

5 influent volume $\left(\mathrm{l} /\right.$ week per $\left.\mathrm{m}^{2}\right) \times$ influent concentration $(\mathrm{mg} / \mathrm{l})$ 1000

and the effluent load $\left(\mathrm{g} /\right.$ week per $\left.\mathrm{m}^{2}\right)$ is equal to

effluent volume (l/week per $\left.\mathrm{m}^{2}\right) \times$ effluent concentration $(\mathrm{mg} / \mathrm{l})$ 1000

The treatment mechanisms within each of the systems cannot be demonstrated from this study; they can, however, be inferred from an evaluation of the process by-products. There are two potential mechanisms operating in the upper levels of the test systems following oxidation of the influent ammonium to nitrite. Either nitrification is occurring completely with immediate denitrification or the nitrite is immediately converted to nitrogen by anammox bacteria in a process consistent with conclusions drawn in other trials on wetland systems. ${ }^{29}$ anammox has two advantages over traditional nitrification and denitrification.

(a) Anammox is more energetically favourable than nitrification of nitrite (for anammox, Gibbs free energy $\Delta G$ is $-357 \mathrm{KJ} /$ mol; for nitrification, $\Delta G$ is $-275 \mathrm{KJ} / \mathrm{mol}^{30,31}$ ). (b) A separate carbon source is not required for anammox, unlike denitrification (Equations 3 and 4).

Anammox is a process that only requires ammonium and nitrite and therefore minimises the oxygen demand for the treatment of ammonium. In a constructed wetland system, the available oxygen can be utilised for the conversion of ammonium to nitrite and this nitrite can then be utilised for the conversion of an equivalent amount of ammonium and effectively double the process efficiency. Within the oxygen-limited environment of a saturated vertical flow wetland, this partial nitrification under aerobic conditions adjacent to plant rootlets followed by conversion to nitrogen through reactions with remaining ammonium on the microcosm scale is therefore an ideal sustainable process as no other reactants are required.

The importance of oxygen-limited conditions in overall nitrogen removal is demonstrated within this study because the most effective nitrification system resulted in one of the highest overall nitrogen effluents. Although influent ammoniacalnitrogen concentrations of $1400-1600 \mathrm{mg} / \mathrm{l}$ were reduced to less than $5 \mathrm{mg} / \mathrm{l}$ (in IBC3), a proportion of the nitrate was not denitrified during autumn and early winter (Figure 5). In contrast, where concurrent ammonium oxidation and nitrate/ nitrite reduction are occurring at equivalent rates, the total nitrogen content of the resulting effluent is significantly lower (Table 3).

Effective ammonium and nitrogen treatment is only limited in oxygen-rich environments when nitrification activity rates are in excess of the anammox activity. Once there is complete nitrification, anammox cannot be sustained and a high nitrate effluent will be formed, which may in part explain the difference in performance between IBC1 and IBC4. Any successive denitrification stage will require a combination of anoxic conditions and a carbon source (Equation 3).

The level of treatment observed in this study is significantly higher than that reported in other studies. Ammoniacal-nitrogen reduction rates of $1-38 \%{ }^{29}$ and concentration reduction from 422 to $160 \mathrm{mg} / \mathrm{l}$ from a series of $95 \mathrm{~mm}$ diameter by $900 \mathrm{~mm}$ columns are significantly lower than the 69-99\% identified in 
this study. The increased treatment performance observed here is likely to be a consequence of the reduced hydraulic loading rate of $0.01 \mathrm{~m}^{3} / \mathrm{m}^{2}$ per day compared with $0.19 \mathrm{~m}^{3} / \mathrm{m}^{2}$ per day used in the Sun and Austin trials, ${ }^{29}$ typical for vertical flow reed bed systems. Reduced hydraulic loading limits the amount of ammoniacal-nitrogen requiring treatment and hence a greater performance can be achieved. In addition, use of the artificial compost-soil-sand mixture in this study significantly increases the surface area available to support a biomass population compared with typical wetland substrates - that is, gravel.

The design capacity of a nitrifying bioreactor is based on a combination of the biological hydraulic residence times (HRTs) necessary for the biological process and the expected throughput of the plant. Typical HRTs for nitrifying bioreactors such as SBRs are of the order of 8-12 days to achieve full nitrification of landfill leachate ${ }^{32}$ and overcome ammonia toxicity to the biomass.

Assuming a soil porosity of $20 \%$ and that aerobic treatment is restricted to the upper $0.25 \mathrm{~m}$ of the soil profile, then a pore space of $0.05 \mathrm{~m}^{3}$ per $\mathrm{m}^{2}$ of wetland surface area (SA) is available. This is equivalent to an HRT of five days (Equation 7) for aerobic-dominated treatment by managing the saturation level within the system to within $0.05 \mathrm{~m}$ of the surface. Taking the $0.75 \mathrm{~m}$ depth profile into account, a 12-15-day HRT is available (including average rainfall volumes), which is comparable to the 8-12 days necessary for aerated biological reactors, but significantly higher than the hydraulic loading rates for other wetland investigations. ${ }^{29}$ The HRT is given by

\begin{tabular}{|l|l|}
\hline 7 & HRT $($ days $)=\frac{\text { pore space }\left(\mathrm{m}^{3}\right)}{\text { dose rate }\left(\mathrm{m}^{3} / \text { day }\right)}$ \\
\hline
\end{tabular}

Thus, in this study

\begin{tabular}{|l|l|}
\hline HRT & $=\frac{0.05 \mathrm{~m}^{3} \text { per } \mathrm{m}^{2} \text { SA }}{0.01 \mathrm{~m}^{3} \text { leachate per } \mathrm{m}^{2} \text { SA per day }}$ \\
& $=5$ days per $0.25 \mathrm{~m}$ of profile
\end{tabular}

and in the Sun and Austin trials ${ }^{29}$

$\begin{aligned} \text { HRT } & =\frac{0.05 \mathrm{~m}^{3} \text { per } \mathrm{m}^{2} \text { SA }}{0.19 \mathrm{~m}^{3} \text { leachate per } \mathrm{m}^{2} \text { SA per day }} \\ & =0.26 \text { days }\end{aligned}$

To maintain a five-day HRT in the upper $0.25 \mathrm{~m}$ of the system, a minimum vertical seepage velocity of $0.05 \mathrm{~m} /$ day or $6 \times 10^{-7} \mathrm{~m} / \mathrm{s}$ would need to be sustained for the operational life of the wetland. Natural soils are unlikely to be able to maintain such permeabilities, but suitable alternatives are available. Materials and seepage rate monitoring during this trial has identified that substrate permeability can be significantly modified with compost. Testing of bulk and blended materials by flooding the surface of the test wetlands by $0.25 \mathrm{~m}$ of water and monitoring infiltration rates over 17 hour periods while actively abstracting from the drainage layer gave permeabilities of $1.6 \times 10^{-3} \mathrm{~m} / \mathrm{s}$ for compost,

$2 \cdot 1 \times 10^{-5} \mathrm{~m} / \mathrm{s}$ for artificial soil (80\% sand) and $1.8 \times 10^{-4} \mathrm{~m} / \mathrm{s}$ for a 50:50 compost-soil mix.
These permeabilities are sufficiently high to allow passive overflow to control the saturation level for compost and artificial soil substrate when the level is managed by an adjacent level control chamber linked to an underlying drainage layer. Alternatively, a continuous low-flow pump can be operated in place of a passive overflow to maintain a constant saturation level within the wetland profile.

Sustainability of the constructed wetland and optimisation of the process is a balance between an engineered design that will allow sufficient long-term flow through a soil matrix (i.e. greater than ten years) and will also provide a support matrix for the treatment biomass. The preferred aerobic-anaerobic interfaces and bacterial population can be promoted by careful culturing, saturation level control and stepped increases in load in excess of the oxygenating potential of the planted system during commissioning.

Selection of a treatment system is based on a combination of initial capital costs, management requirements and associated costs over the lifetime of the plant, which, for landfill, is likely to be of the order of 10 to 25 years. The primary advantage of a wetland system is the minimal maintenance and management required during its operational life. With regard to landfill sites, there is the option to integrate the system into the final restoration surface. The landfill cap can act as a basal seal and the standard $1 \mathrm{~m}$ above-cap protection and restoration layer is consistent with the required soil profile and hence does not require the importation of additional materials.

In addition to the operational sustainability advantages of constructed wetlands, in the long term the systems can be converted to ecological features and remain in situ without decommissioning, dismantling and removal from site. These advantages come at the expense of an increased commissioning period for a constructed wetland compared with other treatment processes. Typical commissioning periods for aerated biological reactors are four to six weeks and influent loads can be doubled over an eight- to ten-day cycle. However, commissioning of constructed wetlands must take seasonal considerations into account to allow for plant establishment and root development to allow an oxygen transfer network into the soil substrate as well as a slow bacterial growth rate. Assuming engineering construction over a spring-summer period, this type of constructed wetland would take up to 12 months before being fully operational. Although this is an extended period, these timescales are minimal compared with the proposed operational life of the system.

\section{ACKNOWLEDGEMENTS}

The authors are grateful for technical and financial assistance for this project under the landfill tax credit scheme, administered by Entrust with support from Viridor Waste Management Ltd, Cory Environmental Ltd and the Engineering and Physical Sciences Research Council.

\section{REFERENCES}

1. Robinson H. R., HaRris G. R. and Truscott S. Use of reedbed systems to provide environmentally friendly control of leachate from old landfills: ten years of experience from a site in Wiltshire. Communications in Waste and Resource Management, 2008, 9, No. 1, 31-41. 
2. Stone K. C., Poach M. E., Hunt P. G. and Reddy G. B. Marsh-pond-marsh constructed wetland design analysis for swine lagoon wastewater treatment. Ecological Engineering, 2004, 23 No. 2, 127-133.

3. Öövel M., Tooming A., Mauring T. and Mander Ü. Schoolhouse wastewater purification in a LWA-filled hybrid constructed wetland in Estonia. Ecological Engineering, 2007, 29, No. 1, 17-26.

4. GRIFFIN P. Ten years experience of treating all flows from combined sewerage systems using package plant and constructed wetland combinations. Water Science and Technology, 2004, 48, No. 11, 93-99.

5. Sheoran A. S. Acid mine drainage treatment on bench scale wetland with saccharum bengalense. Mineral Processing and Extractive Metallurgy: IMM Transaction Section C, 2007, 116, No. 1, 48-53.

6. Konhauser K. O., Mortimer R., Morris K. M. and Dunn V. Interactions of microorganisms during sediment diagenesis: implications for radionuclide mobility. In Interactions of Microorganisms with Radionuclides (Kerth-Roach M. J. and Livens F. R. (eds)). Elsevier Science, Oxford, 2002 pp. 63-100.

7. Madigan M. T., Martinko J. M. and Parker J. Brock Biology of Microorganisms, 10th edn. Prentice-Hall, London, 1997.

8. BERNER R. A. Early Diagenesis: A Theoretical Approach. Princeton University Press, Princeton, NJ, 1980.

9. Froelich P. N., Klinkhammer G. P., Bender M. L., LuedtKe N. A., Heath G. R., Cullen D., Dauphin P., Hammond D., HARTMAN B. and MAYNARD V. Early oxidation of organic matter in pelagic sediments of the eastern equatorial Atlantic: suboxic diagenesis. Geochimica et Cosmochimica Acta, 1979, 43, No. 7, 1075-1090.

10. Robertson L. A., Cornelisse R., De Vos P., Hadioetomo R. and Kuenen J. G. Aerobic denitrification in various heterotrophic nitrifiers. Antioine van Leeuwenhoek, 1989, 56, No. 4, 289-299.

11. Bartlett R., Mortimer R. J. G. and Morris K. Anoxic nitrification: evidence from Humber Estuary sediments (UK). Chemical Geology, 2008, 250, No. 1-4, 29-39.

12. Henze M., Harremores P., Jansen J. L. C. and Arvin E. Wastewater Treatment: Biological and Chemical Processes. Springer, Berlin, 2002.

13. Aller R. C., Mackin J. E., Ullman W. J., Chen-Hou W., Shing-Min T., Jian-Cai J., Young-Nian S. and Jia-ZHen H. Early chemical diagenesis, sediment water solute exchange and storage of reactive organic matter near the mouth of the Changkiang, East China Sea. Continental Shelf Research, 1984, 4, No. 1-2, 227-251.

14. Jetten M. S. M., Logemann S., Muyzer G., Robertson L. A., Devries S., Vanloosdrecht M. C. M. and Kuenen J. G. Novel principles in the microbial conversion of nitrogen compounds. Antonmie van Leeuwenhoek, 1997, 71, No. 1-2, 75-93.

15. Tredje M. J., Sexstone A. J., Myrold D. D. and Robinson J. A. Denitrification: ecological niches, competition and survival. Antonie van Leeuwenhoek, 1982, 48, No. 6, 569-583.

16. Mulder A., van de GraAf A. A., Robertson L. A. and KUENEN J. G. Anaerobic ammonium oxidation discovered in a denitrifying fluidized bed reactor. FEMS Microbiology Ecology, 1995, 16, No. 3, 177-184.
17. van de Graaf A. A., Mulder A., De Bruign P., Jetten M. S. M., Robertson L. A. and Kuenen J. G. Anerobic oxidation of ammonium is a biologically mediated process. Applied Environmental Microbiology, 1995, 61, No. 4, 1246-1251.

18. Trimmer M., Nicholls J. C. and Deflandre B. Anaerobic ammonium oxidation measured in sediments along the Thames Estuary, United Kingdom. Applied and Environmental Microbiology, 2003, 69, No. 11, 6447-6454.

19. Thamdrup B. and DalsgaArd T. Production of $\mathrm{N}_{2}$ through anaerobic ammonium oxidation coupled to nitrate reduction in marine sediments. Applied and Environmental Microbiology, 2002, 68, No. 3, 1312-1318.

20. Engstrom P., Dalsgaard T., Hulth S. and Aller R. C. Anerobic ammonium oxidation by nitrite (anammox: implications for $\mathrm{N}_{2}$ production in coastal marine sediments. Geochemica et Cosmochimica Acta, 2005, 69, No. 8, 2057-2065.

21. Jetten M. S. M., Strous M., van de Pas-Schoonen K. T., Schalk J., van Dongen U. G., van de GraAf A. A., Logemann S., Muyzer G., Loosdrecht M. C. M. and Kuenen J. G. The anaerobic oxidation of ammonium. FEMS Microbiology Reviews, 1999, 22, No. 5, 421-437.

22. FAnNIN C. A. HaloTech ${ }^{\mathrm{TM}}$ wetland systems for primary wastewater treatment system development and performance overview. Proceedings of European Water and Wastewater Management Conference (HoRAN N. (ed.)). Aqua Enviro, West Yorkshire, 2007.

23. WinfreY M. R. and WARD D. M. Substrates for sulphate reduction and methane production in intertidal sediments. Applied and Environmental Microbiology, 1983, 45, No. 1, 193-199.

24. Maricle B. R. and Lee R. W. Aerenchyma development and oxygen transport in the estuarine cordgrasses Spartina alterniflora and S. anglica. Aquatic Botany, 2002, 74, No. 2, 109-120.

25. Holmer M., Gribsholt B. and Kristensen E. Effects of sea level rise on growth of Spartina anglica and oxygen dynamics in rhizosphere and salt marsh sediments. Marine Ecology Progress Series, 2002, 225, 197-204.

26. EgER P. Wetland treatment for trace metal removal from mine drainage: the importance of aerobic and anaerobic processes. Water Science and Technology, 1994, 29, No. 1, 249-256.

27. Vymazal J. Horizontal sub-surface flow and hybrid constructed wetlands systems for wastewater treatment. Ecological Engineering, 2005, 25, No. 5, 478-490.

28. Fannin C., Wakelin D., Roberts D., Danes P. and Collings J. HaloTech wetland systems for primary wastewater treatment. Proceedings of Waste 2006, Sustainable Waste \& Resource Management (VEGH B. and Royce J. (eds)). The Waste Conference, Coventry, 2006, 177-186.

29. Sun G. and Austin B. Completely autotrophic nitrogenremoval over nitrite in lab-scale constructed wetlands: evidence from a mass balance study. Chemosphere, 2007, 68, No. 6, 1120-1128.

30. Strous M., Kuenen J. H. G. and Jetten M. S. M. Key physiology of anaerobic ammonium oxidation. Applied 
and Environmental Microbiology, 1999, 65, No. 7, 3248-3250.

31. JetTen M. S. M. New pathways for ammonia conversion in soil and aquatic systems. Plant and Soil, 2001, 230,

No. 1, 9-19.
32. EnVironment Agency. Guidance for the Treatment of Landfill Leachate. EA, Bristol, 2007, Sector Guidance Note IPPC S5.03.

\section{What do you think?}

To comment on this paper, please email up to 500 words to the editor at journals@ice.org.uk

Proceedings journals rely entirely on contributions sent in by civil engineers and related professionals, academics and students. Papers should be 2000-5000 words long, with adequate illustrations and references. Please visit www.thomastelford.com/journals for author guidelines and further details. 